\title{
Attendance and Co-Occurrence of Birds Following Army Ants in the Atlantic Rain Forest
}

Author(s): Marco Aurélio Pizo and Adriano S. Melo

Source: The Condor, 112(3):571-578.

Published By: Cooper Ornithological Society

URL: http://www.bioone.org/doi/full/10.1525/cond.2010.090057

BioOne (www.bioone.org) is a nonprofit, online aggregation of core research in the biological, ecological, and environmental sciences. BioOne provides a sustainable online platform for over 170 journals and books published by nonprofit societies, associations, museums, institutions, and presses.

Your use of this PDF, the BioOne Web site, and all posted and associated content indicates your acceptance of BioOne's Terms of Use, available at www.bioone.org/page/terms of use.

Usage of BioOne content is strictly limited to personal, educational, and non-commercial use. Commercial inquiries or rights and permissions requests should be directed to the individual publisher as copyright holder. 


\title{
ATTENDANCE AND CO-OCCURRENCE OF BIRDS FOLLOWING ARMY ANTS IN THE ATLANTIC RAIN FOREST
}

\author{
Marco Aurélio Pizo ${ }^{1,3}$ and Adriano S. Melo 2,4 \\ ${ }^{1}$ UNESP_Universidade Estadual Paulista, Departamento de Zoologia, 13506-900 Rio Claro, São Paulo, Brazil \\ ${ }^{2}$ Universidade Federal do Rio Grande do Sul, Instituto de Biociências, Departamento de Ecologia, CP 15007, $91501-970$ \\ Porto Alegre, Rio Grande do Sul, Brazil
}

\begin{abstract}
In a first attempt to formally test competitive interactions among army-ant-following birds, we explored the patterns of occurrence of birds following swarms of army ants in the Atlantic rain forest of southeastern Brazil. We contrasted the frequency of occurrence of birds at ant swarms at a lowland and a highland site. Additionally, we assessed the patterns of co-occurrence of bird species at ant swarms, using null models to test for the possibility of competitive exclusion. Despite the larger number of attending bird species at the highland site, we detected no differences between the sites in either the frequency of attendance or the number of bird species per swarm. Analyses of co-occurrence did not reveal evidence of negative association of bird species attending ant swarms at the lowland site but did at the more species-rich highland site. Pairwise analyses showed that this negative association invariably involved two of the species attending ant swarms most frequently, Pyriglena leucoptera and Trichothraupis melanops, suggesting a competitive interaction. Possibly, although birds that are more dependent upon army ants avoid competitive exclusion by spatial segregation at the swarm's front, birds that follow army ants less frequently are occasionally excluded from the swarms.
\end{abstract}

Key words: army ants, Atlantic forest, Brazil, competitive interactions, null models, Pyriglena leucoptera, Trichothraupis melanops.

Presencia y Co-presencia de Aves que Siguen Hormigas Legionarias en la Selva Atlántica

Resumen. En un primer intento por probar formalmente la existencia de interacciones competitivas entre aves que siguen hormigas legionarias, exploramos los patrones de presencia de las aves que siguen enjambres de estas hormigas en la selva lluviosa Atlántica del sudeste de Brasil. Contrastamos la frecuencia de presencia de aves en enjambres de hormigas en un sitio de tierras bajas y en uno de tierras altas. Además, evaluamos los patrones de presencia simultánea de las especies de aves en los enjambres usando modelos nulos para evaluar la posibilidad de exclusión competitiva. A pesar de que se encontró un mayor número de especies siguiendo los enjambres en el sitio de tierras altas, no detectamos diferencias entre sitios en la frecuencia de presencia ni en el número de especies por enjambre. Los análisis de presencia simultánea no mostraron evidencia de asociación negativa entre las especies que seguían a los enjambres en el sitio de tierras bajas, pero sí en el sitio más rico en especies ubicado en tierras altas. Análisis por pares demostraron que esta asociación negativa invariablemente involucró a dos de las especies que seguían enjambres más frecuentemente, Pyriglena leucoptera y Trichothraupis melanops, lo que sugiere una interacción competitiva. Posiblemente, aunque las aves que son más dependientes de las hormigas evitan la exclusión competitiva mediante separación espacial en el frente de los enjambres, las aves que siguen a las hormigas con menos frecuencia ocasionalmente son excluidas de los enjambres.

\section{INTRODUCTION}

Army-ant-following birds are a prominent feature of tropical forests, tracking swarms of army ants to prey on invertebrates and small vertebrates flushed by the moving raid (Willis and Oniki 1978). A wide variety of bird species follow ant swarms in neotropical forests, but the degree of specialization varies: occasional (or opportunistic) followers forage at swarms opportunistically, regular followers attend swarms beyond their territories but are also often found foraging independently of swarms, while obligate (or "professional") followers are species that are apparently incapable of foraging independently of swarms or other beaters of prey (e.g., monkeys, peccaries; Willis and Oniki 1978, Willson 2004, Brumfield et al. 2007). Although occasional followers are widespread throughout the Neotropical Region, obligate followers seem to be restricted to Amazonian and Central American forests, where up to five obligate followers may occur sympatrically (Willson 2004,

Manuscript received 2 April 2009; accepted 3 March 2010.

${ }^{3}$ E-mail: pizo@rc.unesp.br

${ }^{4}$ Current address: Universidade Federal de Goiás, Instituto de Ciências Biológicas, Departamento de Biologia Geral, CP 131, 74001-970 Goiânia, Goiás, Brazil.

The Condor, Vol. 112, Number 3, pages 571-578. ISSN 0010-5422, electronic ISSN 1938-5422. @ 2010 by The Cooper Ornithological Society. All rights reserved. Please direct all requests for permission to photocopy or reproduce article content through the University of California Press's Rights and Permissions website, http://www.ucpressjournals.com/ reprintInfo.asp. DOI: $10.1525 /$ cond.2010.090057 
Brumfield et al. 2007). For the Brazilian Atlantic forest, Faria and Rodrigues (2009) classified Pyriglena leucoptera as an obligate follower on the basis of its behavior of checking bivouacs (i.e., temporary ant nests) to keep track of the ants' movements (Swartz 2001). The dependence of $P$. leucoptera upon army ants, however, is certainly not as marked as in the true obligate species (species that are never seen foraging away from army ants or other beaters of prey) of the Amazonian and Central American forests, because P. leucoptera is commonly seen foraging away from prey flushers (del Hoyo et al. 2003; Pizo, pers. obs.).

Army-ant-following birds have been shown to compete interspecifically at ant swarms, resulting in dominance hierarchies driven mainly by size. Larger and dominant species usually occupy the more profitable central region of the swarm, whereas subordinate species are progressively displaced to the periphery of the swarm's front (Willis and Oniki 1978). In addition, birds may segregate themselves by perch height and position (Coates-Estrada and Estrada 1989). Wellestablished dominance hierarchies and spatial segregation permit the coexistence of many bird species and individuals at a given swarm (up to 60 individuals have been recorded; Chaves-Campos 2005) but do not preclude the competitive exclusion of some species. For instance, Willis (1966) suggested that dominant, resident birds exclude migrant, subordinate species from ant swarms at Barro Colorado Island, Panama. Similarly, Rios et al. (2008) noted that when some dominant bird species were following ant swarms in the Andean highlands of Colombia, no other birds were seen. Therefore, obligate ant followers tend to be dominant over occasional ant followers.

In the Neotropical Region, army-ant-following birds have been studied extensively in the Amazon and Central America, to a lesser extent in the Andes (Gochfeld and Tudor 1978, Willis and Oniki 1978, Coates-Estrada and Estrada 1989, Willson 2004, Rios et al. 2008). Apart from the paper by Faria and Rodrigues (2009), only scattered reports of bird species following army ants are available for the Atlantic forest (e.g., Willis and Oniki 1992). With elevations extending from 0 to $>2000 \mathrm{~m}$ above sea level, and climate conditions varying accordingly, birds' reliance on army ants in the Atlantic forest may vary along the altitudinal gradient. This variation arises not only because army-ant density may vary spatially, but also because ant activity responds to climate factors (O'Donnell et al. 2007). O'Donnell and Kumar (2006), for instance, found in Central America that rates of army-ant raids decreased with increasing elevation. Therefore, significant differences are likely both within the Atlantic forest and between the Atlantic forest and other regions of the neotropics, as reliance on army ants may vary geographically (Willis 1985, Robinson and Terborgh 1995). Such differences could reveal historical, climatic, and ecological factors influencing the composition of and competitive interactions among army-ant-following birds. In particular, the lack of true obligate followers in the
Atlantic forest offers an interesting opportunity for study of the behavioral interactions among ant followers.

Here we present data on the occurrence of birds at swarms of Eciton burchelli and Labidus praedator (both members of the Ecitoninae; from now on referred to only by their generic names), the two species of ants most frequently followed by birds in the neotropics (Willis and Oniki 1978) and at both low and high elevations in the Atlantic forest of southeastern Brazil. Our objectives were twofold: first, to describe and compare the species composition and frequency of occurrence of birds at ant swarms at two elevations within the Atlantic forest and between the Atlantic forest and elsewhere in the neotropics; second, to evaluate patterns of co-occurrence among species, to test the possibility of competitive exclusion among army-antfollowing birds. Competitive exclusion may result in a perfect checkerboard distribution when a given swarm is followed by only one of two competing bird species. We looked for pairs of species distributed in a checkerboard and tested with null models whether the frequency of checkerboard distributions was nonrandom among swarms. This approach has been used to test for competitive exclusion among bird species participating in mixed-species flocks (Graves and Gotelli 1993) but has never been applied to army-ant-following birds. The test evaluates whether the observed pattern of co-occurrence differs from a random association of species. The detection of a nonrandom pattern does not imply the existence of competition, however, because other mechanisms may produce the pattern (Gotelli and Graves 1996). Accordingly, we used evidence from the tests and knowledge of the natural history of the birds to interpret the results.

\section{STUDY AREAS AND METHODS}

\section{STUDY AREAS}

Data for this study were recorded during visits from 1991 to 2001 to two sites at different altitudes within the Parque Estadual Intervales $\left(24^{\circ} 16^{\prime} \mathrm{S}, 48^{\circ} 25^{\prime} \mathrm{W}\right)$, a $490-\mathrm{km}^{2}$ reserve of Atlantic Rain Forest (sensu Morellato and Haddad 2000) in southeastern Brazil. The study sites, the Saibadela and Carmo research stations, lie at 70 and $700 \mathrm{~m}$ above sea level and encompass lowland and highland areas of the reserve, respectively. The straight-line distance between them is about $25-30 \mathrm{~km}$.

The vegetation at the lowland site consists of old-growth forest and small patches of secondary growth near human settlements (Guilherme et al. 2004). The highland vegetation, in contrast, is mainly late secondary with patches of old-growth forest (Nascimento 1994). Both sites are crossed by trails 1-2 m wide that alter the surrounding vegetation minimally; ant swarms can be found along these trails. The temperature (annual mean $\sim 24^{\circ} \mathrm{C}$, range $\left.3-42^{\circ} \mathrm{C}\right)$ and precipitation $\left(\sim 4000 \mathrm{~mm} \mathrm{yr}^{-1}\right)$ at the lowland site are higher than at the highland site (annual mean temperature $\sim 17^{\circ} \mathrm{C}$, range $-4-38^{\circ} \mathrm{C}$; annual precipitation $\sim 1900 \mathrm{~mm} \mathrm{yr}^{-1}$ ). At both sites, there is a period of cold, dry weather from April to August (more pronounced at the 
highland site) and of warm, wet weather from September to March (more pronounced at the lowland site).

Totals of 234 and 325 bird species occur at the lowland (Aleixo and Galetti 1997) and highland sites (Vielliard and Silva 2001), respectively, including 60 species of Dendrocolaptidae, Thamnophilidae, and Thraupidae, families typically associated with army ants in the neotropics (Willis and Oniki 1978). The greater species richness in the highland is at least partially explained by the greater habitat heterogeneity caused by the vegetation mosaic of different successional stages, which contrasts with the more homogeneous old-growth forest of the lowland.

\section{METHODS}

Pizo found ant swarms opportunistically while walking along the trails crossing the study sites. Every time a swarm was found, the species of ant and birds following it were recorded. Swarms were followed for 5-15 min until the observer was confident that all bird species were recorded; a bird was only recorded if it was clearly foraging amid the ant swarm. No attempt was made to count the number of individual birds following ants. Therefore, analyses were based on the frequency of occurrence of each species of bird at the swarms. Fifty ant swarms were found, 28 at the highland site and 22 at the lowland site. We did not identify the species of ant in one and ten of the lowland and highland swarms, respectively. As a result, when we considered the two ant species separately, the number of swarms with following birds was too small to allow analyses that contrasted the two ant species at each site. Therefore, unless otherwise noted, we pooled the ant species for analyses, with some potential biases. Eciton and Labidus differ in the frequency of their foraging and, therefore, in their reliability to birds. In contrast to Labidus, Eciton forages nearly every day and is therefore a more dependable source of flushed prey (Willis and Oniki 1978, Gotwald 1995). If birds differ in their propensity to follow swarms of Eciton and Labidus, then the patterns of co-occurrence for each ant species may include heterogeneity when data for both ants are pooled. However, the relative contributions of Eciton and Labidus at each site were similar, contributing to the reliability of the comparisons of the two sites.

To compare the frequency of bird attendance at ant swarms at the two sites with ant species pooled, and to test for differences between Eciton and Labidus in the frequency of birds attending their swarms with data from the two sites pooled, we used a log-likelihood ratio test ( $G$-test) with Yates' correction. To compare the sites with respect to the number of bird species per swarm, we used a general linear model, equivalent to a $t$-test but based on a Poisson distribution, appropriate for our count data, which included many zeroes. To check if the local abundances of birds were a good predictor of their attendance at ant swarms, we first carried out an overall $G$-test for each site, which contrasted the frequency of swarm attendance with the expected frequency proportional to the abundance of the species. These tests included all species except those not detected during the point-count studies described below. Because the results of these tests were significant, we then performed similar tests with Yates' correction for each species of bird. Abundances were based on point-count studies conducted concurrently with our study by Aleixo (1997) at the lowland site and Vielliard and Silva (2001) at the highland site. Unlimited-distance counts of 20 min were made at 163 points at the lowland site and 90 points at the highland site. The abundance of each species was expressed as the index of point abundance, the ratio between the total number of records (visual or aural) of the species during point counts and the total number of points sampled (Blondel et al. 1981).

\section{CO-OCCURRENCE ANALYSES}

Using null models, we tested whether the birds' co-occurrence at swarms was nonrandom. The long dispute over whether competition results in a checkerboard distribution of species has led to the development of a multitude of statistics to measure co-occurrence and algorithms to randomize data (Gotelli 2000). We followed the suggestions of Gotelli (2000) and used combinations of statistics and randomization algorithms, resulting in low probabilities of type I and type II errors. Because different procedures can produce contrasting results, we employed more than one null model to check the robustness of our conclusions.

We used the $C$-score proposed by Stone and Roberts (1990) to measure co-occurrences among species of birds. This statistic is the mean of the checkerboard units among all pairs of species. The procedures to randomize data differ basically with respect to whether the number of occurrences of each species (row sums) and the number of species in each swarm (column sums) in random matrices is maintained or not. We employed three models, and in all cases the row sums were maintained. Our option to maintain row sums in null models aimed at maintaining the pattern of common and rare species observed in the original data, and precluding type I errors (Gotelli 2000). In our first model we maintained column sums as in the SIM9 model of Gotelli (2000), among the first models used in the analysis of co-occurrence (Connor and Simberloff 1979). This null model preserves, in addition to the pattern of common and rare species (fixed row sums), species richness of birds in each ant swarm (fixed column sums) and so could be regarded as the model that best matches the biological characteristics of the observed data. This model is, however, very restrictive with respect to random shuffling of data. In the second model, column sums were proportional to the original data (SIM4). The number of bird species at each swarm was on average similar to the values observed in the original data. This model maintains most of the characteristics of model SIM9 but allows for greater combinations of shuffled data. The last model (SIM2) treated attendance at each swarm as equally probable, and on average each swarm had the same number of attending bird species. Although in comparison to the 
two previous models SIM2 imposes few restrictions on shuffling, it does not retain information on species richness per swarm. It could be interpreted as meaning that if all swarms are equally attractive to birds, differences among swarms in bird species richness result simply by chance.

We used the three null models to analyze data from each site separately. At both sites, some swarms had no attending birds. Because the inclusion or exclusion of these swarms can affect results of the co-occurrence analyses by models SIM2 and SIM4, we repeated the analyses for data including all swarms and for data including only swarms attended by at least one bird. The inclusion of birdless swarms in the analysis is based on the view that in communities strongly structured by competition birdless swarms should be rare. As soon as a swarm forms, weak competitors with high ability to find swarms should colonize them and remain until the arrival of stronger competitors. A high frequency of birdless swarms could thus be interpreted as evidence of a lack of competition.

Models SIM2 and SIM4 may produce degenerate matrices in which no bird species attends a simulated swarm. In the analyses using the full dataset including birdless swarms, we retained degenerate matrices because they are equivalent to swarms observed in the real dataset. In the analyses excluding birdless swarms, we discarded degenerate matrices. Using the software Ecosim (Gotelli and Entsminger 2001), we carried out 10 analyses of co-occurrence ([2 sites $\times 2$ models [SIM2, SIM4 $] \times 2$ data matrices $]+[2$ sites $\times 1$ model [SIM9]]), all with 10000 randomizations.

In case of significant evidence against co-occurrence, we investigated which pairs of species most contributed to the pattern. We employed the number of checkerboard units as a measure of association for each species pair. Note that the $C$ score is simply the mean of all values of checkerboard units for all species pairs. The number of checkerboard units for each pair of species is affected by the species' number of occurrences and so cannot be used directly to assess the association of species pairs. Accordingly, we used null models (both SIM2 and SIM 4) to ascertain whether the numbers of checkerboard units observed for a species pair were higher than those obtained by simulation. Many swarms had no bird of a given pair of species, possibly affecting the results, so we repeated analyses for data including all swarms and data including swarms attended by at least one individual of the species pair. Both null models and data types gave similar results: the correlation among $P$-values of the matrices ranged from 0.707 to 0.998 ; all four analyses yielded the same significant (at $5 \%$ level) species pairs. We therefore opted to present the results from the most conservative analysis (SIM2 and data including all swarms, with and without either of the two bird species). It should be noted that in each analysis, many $P$-values were generated; for instance, 15 bird species results in 105 comparisons $[(15 \times 14) / 2]$, so some probabilities significant at the 0.05 level can be produced by chance alone. On the other hand, the low number of rows (2) results in a test with low statistical power (Gotelli and McCabe 2002), so the tests are conservative. We analyzed the pairs of species with a routine written in the R environment (R Development Core Team 2007).

\section{RESULTS}

We found that most ant swarms at both sites were followed by birds, with no difference between the sites in bird attendance $(G=0.47, \mathrm{df}=1, P=0.49$; Table 1$)$. Eciton formed the majority $(55 \%)$ of swarms at the lowland site, and at the highland site seven of 12 swarms in which the ant was identified were also of Eciton. Overall, Eciton attracted birds more frequently than did Labidus $(G=3.89, \mathrm{df}=1, P=0.05)$.

We identified 18 species of birds of eight families at the ant swarms (Table 2). The number of bird species per swarm at the two sites did not differ (difference in deviance $=2.142$, $P=0.143$; Table 1). At both sites, Pyriglena leucoptera and Trichothraupis melanops were the birds following ant swarms most frequently (Table 2). Overall, the local abundances of birds did not predict their attendance at ant swarms, neither at the lowland $(G=43.25, \mathrm{df}=9, P<0.001)$ nor at the highland site $(G=26.02, \mathrm{df}=11, P=0.006)$. P. leucoptera and T. melanops attended ant swarms more often than expected from their abundances at the lowland site, whereas Formicarius colma and Xiphorhynchus fuscus were detected with swarms less often than expected (Table 2). At the highland site, we found T. melanops positively and Sittasomus griseicapillus negatively associated with ant swarms (Table 2). For all other species, the frequency of occurrence at swarms did not significantly deviate from what would be expected from its local abundance.

At the lowland site, we did not detect any significant checkerboard distributions among birds following army ants (Table 3). At the highland site, results of four of the five analyses

TABLE 1. Statistics for the ant swarms (Eciton burchelli and Labidus praedator) and their following birds observed at lowland and highland sites in Parque Estadual Intervales, Brazilian Atlantic forest.

\begin{tabular}{lcc}
\hline \hline Variable & Lowland & Highland \\
\hline Number of swarms (\% with birds) & $28(64.3)$ & $22(77.3)$ \\
Eciton $^{\text {a }}$ & $15(80.0)$ & $7(71.4)$ \\
Labidus $^{\text {a }}$ & $12(41.7)$ & $5(40.0)$ \\
Number of bird species & 10 & 15 \\
Eciton & 8 & $6^{\mathrm{b}}$ \\
Labidus & 7 & $4^{\mathrm{b}}$ \\
Bird species per swarm (mean $\pm \mathrm{SD})$ & $2.6 \pm 1.5$ & $2.8 \pm 0.9$ \\
Eciton & $2.4 \pm 1.6$ & $2.6 \pm 0.9$ \\
Labidus & $2.8 \pm 1.8$ & $2.5 \pm 0.7$ \\
\hline
\end{tabular}

${ }^{a}$ The ant species was not identified in one and ten of the swarms sampled at the lowland and highland sites, respectively.

${ }^{\mathrm{b}}$ These figures were based on seven swarms (five of Eciton and two of Labidus) with birds following ants that could be identified. 
TABLE 2. Bird species recorded at ant swarms at the lowland and highland sites in Parque Estadual Intervales, with their proportions of occurrence at swarms and indexes of point abundance (IPA). Asterisks following frequencies indicate birds that followed swarms more or less frequently than expected from their abundances ( $G$-tests with Yates' correction: ${ }^{*} P<0.05 ; * * P<0.01$; ${ }^{* * *} P<0.001$ ). An IPA of zero indicates that the species was not recorded in point counts; a dash denotes species that did not occur at the site specified.

\begin{tabular}{|c|c|c|c|c|}
\hline & \multicolumn{2}{|c|}{ Highland } & \multicolumn{2}{|c|}{ Lowland } \\
\hline & $\begin{array}{c}\text { Proportion } \\
(n=22 \text { swarms })\end{array}$ & $\begin{array}{c}\text { IPA } \\
(n=99 \\
\text { point counts })\end{array}$ & $\begin{array}{c}\text { Proportion } \\
(n=28 \text { swarms })\end{array}$ & $\begin{array}{c}\text { IPA } \\
(n=168 \\
\text { point counts })\end{array}$ \\
\hline \multicolumn{5}{|l|}{ Thamnophilidae } \\
\hline Batara cinerea & 0.05 & 0.04 & 0 & 0 \\
\hline Mackenziana severa & 0.05 & 0.28 & 0 & 0 \\
\hline Dysithamnus mentalis & 0.05 & 0.26 & 0 & 0.29 \\
\hline Myrmotherula gularis & 0.09 & 0.07 & 0.07 & 0.13 \\
\hline Pyriglena leucoptera & 0.55 & 0.48 & $0.44 *$ & 0.13 \\
\hline \multicolumn{5}{|l|}{ Conopophagidae } \\
\hline Conopophaga lineata & 0.09 & 0.11 & - & - \\
\hline Conopophaga melanops & 0 & 0 & 0.15 & 0.41 \\
\hline \multicolumn{5}{|l|}{ Formicariidae } \\
\hline Formicarius colma & 0.05 & 0 & $0.07 * * *$ & 1.08 \\
\hline Chamaeza spp. ${ }^{\mathrm{a}}$ & 0.05 & - & 0 & - \\
\hline \multicolumn{5}{|l|}{ Dendrocolaptidae } \\
\hline Dendrocolaptes platyrostris & 0.14 & 0.34 & 0.07 & 0.23 \\
\hline Dendrocincla turdina & 0.18 & 0 & 0.37 & 0.46 \\
\hline Sittasomus griseicapillus & $0.09 * *$ & 0.52 & 0.11 & 0.17 \\
\hline Xiphocolaptes albicollis & 0.05 & 0.17 & 0 & 0.24 \\
\hline Xiphorhynchus fuscus & 0 & 0.11 & $0.07 * *$ & 0.39 \\
\hline \multicolumn{5}{|l|}{ Furnariidae } \\
\hline Synallaxis ruficapilla & 0.09 & 0.18 & 0 & 0 \\
\hline \multicolumn{5}{|l|}{ Tyraniidae } \\
\hline Lathrotriccus euleri & 0.05 & 0.14 & 0 & 0.14 \\
\hline \multicolumn{5}{|l|}{ Thraupidae } \\
\hline Trichothraupis melanops & $0.59 * * *$ & 0.06 & $0.30 *$ & 0.04 \\
\hline \multicolumn{5}{|l|}{ Parulidae $T$} \\
\hline Basileuterus rivularis & 0 & 0.08 & 0.07 & 0.05 \\
\hline
\end{tabular}

ancludes C. campanisona and C. meruloides.

TABLE 3. Co-occurrence analyses of army-ant-following birds at lowland and highland sites in Parque Estadual Intervales, southeastern Brazil. Values are probabilities from null models of co-occurrence. In all models, the frequency of occurrence of each species was kept constant (row sums constant). The null models differed in whether the total number of birds in each ant swarm was fixed, proportional, or equally probable, corresponding to models SIM9, SIM4, and SIM2 described by Gotelli (2000), respectively. For each site, simulations were based on both the full dataset and a reduced dataset excluding swarms with no associated birds. Degenerate matrices produced in the simulations were retained for the full datasets and discarded for the reduced datasets.

\begin{tabular}{lcclcr}
\hline \hline & \multicolumn{2}{c}{ Lowland } & & \multicolumn{2}{c}{ Highland } \\
\cline { 2 - 3 } \cline { 6 - 7 } & $\begin{array}{c}\text { Reduced } \\
(17 \text { swarms })\end{array}$ & $\begin{array}{c}\text { Full } \\
(28 \text { swarms })\end{array}$ & & $\begin{array}{c}\text { Reduced } \\
(17 \text { swarms })\end{array}$ & $\begin{array}{c}\text { Full } \\
(22 \text { swarms })\end{array}$ \\
\hline Fixed (SIM9) & 0.730 & - & & $<0.001$ & - \\
Proportional (SIM4) & 0.866 & 0.494 & & $<0.001$ & $<0.001$ \\
Equally probable (SIM2) & 0.994 & 0.999 & & $<0.001$ & 0.519 \\
\hline
\end{tabular}


were significant $(P<0.001)$ (Table 3$)$, indicating that the cooccurrence of species was less frequent than expected. For the highland site, we explored the pattern of co-occurrence for each pair of species, finding evidence of a checkerboard in five of the 105 pairs of species compared, a rate similar to what we could expect by chance at the $5 \%$ significance level. It should be noted, however, that all five of these pairs involved $P$. leucoptera (with Conopophaga lineata $P=0.076$, Myrmotherula gularis $P=0.065$, and Synallaxis ruficapilla $P=0.076$ ) or $T$. melanops (with $C$. lineata $P=0.034$ and $M$. gularis $P=0.032$ ). Except for $P$. leucoptera and T. melanops, these species were only occasional followers, occurring at only two swarms each, precluding firm conclusions regarding competitive exclusion.

\section{DISCUSSION}

We did not find differences between the lowland and highland sites in the frequency of bird attendance at ant swarms. The overall percentage of ant swarms followed by birds at Parque Estadual Intervales (70\%) is within the range found for sites where obligate ant-followers are absent, which varied from $63 \%$ at Monteverde, Costa Rica (Kumar and O'Donnell 2007), to $80.9 \%$ at Los Tuxtlas, Mexico (Coates-Estrada and Estrada 1989). This percentage is also similar to that at another site in Brazil's Atlantic forest (65\%; Faria and Rodrigues 2009). Even though broad-scale comparisons of bird attendance at ant swarms may be biased because of differences in the methods used to locate the swarms, geographical variation in bird attendance may be typical for sites lacking birds that forage exclusively with ant swarms. Where such birds are present, they keep track of every army-ant colony within their home ranges (Willson 2004), likely resulting in their attending every ant swarm. To test this prediction, attendance data for sites with obligate ant-followers are needed.

Apart from the presence of obligate ant-followers, other factors may lead to geographical variability in bird attendance, such as the previously mentioned geographical variation in the reliance of birds on army ants (Willis 1985, Robinson and Terborgh 1995). For instance, in contrast to observations from other areas, at our study site we did not record at ant swarms any migrants or birds that participate in mixed-species flocks. Mixed-species flocks often follow army ants (Oniki 1971, Coates-Estrada and Estrada 1989), but at our study sites we never recorded common species that frequently join mixedspecies flocks (e.g., Basileuterus culicivorus, Habia rubica) following ants. Similarly, migrants occurring at the study sites (Aleixo and Galetti 1997, Vielliard and Silva 2001) were absent from ant swarms, although migrants form a prominent component of the assemblage of ant-following birds in other areas, especially in Central America (Willis 1966, Dobbs and Martin 1998). Therefore, much remains to be learned about the geographical variation in the reliance of birds on army ants. To this end, a promising avenue of research is the investigation of the geographical variation in army-ant density and foraging activity in combination with the ants' attendance by birds. The rates and daily patterns of foraging raids in neotropical forests vary considerably, potentially influencing the reliability of ant swarms for birds (O’Donnell et al. 2007).

Although the number of bird species per swarm was similar, the total number of attending species at the highland site (15) was higher than at the lowland site (10). Hilty (1974) argued that increased facultative attendance of birds at higherelevation swarms in the Colombian Andes may be attributed to a lack of obligate ant-following birds at higher elevations. Both sites we studied, however, are devoid of obligate ant-followers, so an altitudinal gradient in the attendance of such birds at ant swarms cannot be invoked as the explanation for the difference observed. In the only other comparable study we found, Kumar and O'Donnell (2007) did not find altitudinal differences in the species richness and abundance of birds following army ants within the range of 1100-1680 m at Monteverde, Costa Rica. Therefore additional studies are needed to reveal the altitudinal patterns, if any, in the number of ant-attending bird species in the Neotropical Region. Currently, the simplest explanation for the larger number of attending bird species at the highland site is its avifauna being richer than the lowland site's (Aleixo 1997, Vielliard and Silva 2001). Because most bird species at Parque Estadual Intervales followed ants opportunistically, a richer avifauna should lead to the recording of a larger number of species attending ant swarms.

As found elsewhere (Willis and Oniki 1978, Kumar and O'Donnell 2007, Faria and Rodrigues 2009), most species of birds can be classified as occasional followers. In our study area, the exceptions were Trichothraupis melanops and Pyriglena leucoptera, which followed ants more often than expected by chance. Trichothraupis melanops is already known to follow army ants and other prey flushers (e.g., monkeys; Rodrigues et al. 1994) and is one of the few regular ant-followers in the Atlantic forest. Pyriglena leucoptera is also known to follow ants frequently (Faria and Rodrigues 2009), but its propensity to follow ants at the lowland and highland sites differed. At present, we can only speculate about the reasons underlying this difference, one possibility being the more frequent attendance of T. melanops at the highland swarms. Trichothraupis melanops is known to dominate P. leucoptera in interspecific encounters (Willis and Oniki 1992, Faria and Rodrigues 2009), so it might have displaced P. leucoptera from some highland swarms, though we found no evidence of competitive exclusion between these two species. A simpler, additional explanation is the difference between the sites in abundance of $P$. leucoptera. The lower abundance at the lowland site might have resulted in a lower proportion of swarms being attended, even if birds followed the ants in a proportion higher than their abundance.

The co-occurrence analyses indicated that the observed matrix in the lowland site was not distinct from the matrices 
expected under three null models and two data types (birdless swarms included or excluded). On the other hand, the patterns observed in the highland were distinct from matrices produced by four of the five combinations of null-model analysis, indicating that competition or other mechanisms may have structured bird assemblages. The application of two of the null models for each species pair, however, did not produce firm conclusions about negative interactions between species, in part because of the low attendance of some of the putatively competing species. However, the low attendance of such species may be the result of competition itself. Occasional ant-followers, by definition, do not depend on army ants to reveal food. Their presence at ant swarms, therefore, may be discouraged by the constant aggression of birds that are more dependent on army ants, such as $T$. melanops and $P$. leucoptera (Faria and Rodrigues 2009). For instance, where obligate ant-followers are present, aggression rates may reach seven interactions per minute (Willson 2004). Depending on army ants to a higher degree, regular or obligate ant-followers tolerate and minimize aggression through spatial segregation, as first proposed by Willis and Oniki (1978). They may also alter the amount of space that they use at the swarm front in response to the intensity of competition (Willson 2004). We thus envisage a scenario in which regular and obligate antfollowers are seldom excluded from ant swarms but accommodate themselves along the swarm front through differences in the use of space; while occasional followers, many of them small birds, are occasionally excluded from the swarms. Corroborating this scenario is our observation that the only two regular followers (T. melanops and P. leucoptera) did not exclude each other from ant swarms but excluded some occasional followers at the highland site.

After decades of study, the ecology of ant-following birds is still poorly known (but see Willson 2004), in contrast to the growing body of knowledge about the ecology of army ants (O’Donnell and Kumar 2006, O’Donnell et al. 2007). To sharpen our comprehension of the dynamics of interactions occurring among these birds, formal co-occurrence tests such as those we performed should be attempted. Such tests in areas where obligate ant-followers are present would be especially enlightening. Likewise, the study of ant-following birds in a variety of habitats where ecological conditions (e.g., abundances of birds and food resources) are known would be particularly useful to the understanding of the factors that influence these birds' attendance and dependence upon the ant swarms.

\section{ACKNOWLEDGMENTS}

We thank the staff of the Parque Estadual Intervales for logistical support. The authors received research grants and fellowships from the Conselho Nacional de Desenvolvimento Científico e Tecnológico (CNPq no. 476304/2007-5 and 302482/2008-3 to ASM, and $303559 / 2008-0$ to MAP). ASM was also supported by a grant from the International Foundation for Science (IFS no. A/4107-1).

\section{LITERATURE CITED}

ALEIXO, A. 1997. Estrutura e organização de comunidades de aves em áreas de Mata Atlântica primitiva e explorada por corte seletivo. M.Sc. dissertation, Universidade Estadual de Campinas, Campinas, Brazil.

AleiXo, A., AND M. GALETTI. 1997. The conservation of the avifauna in a lowland Atlantic forest in south-east Brazil. Bird Conservation International 7:235-261.

Blondel, J., C. Ferry, And B. Frochot. 1981. Point counts with unlimited distance. Studies in Avian Biology 6:414-420.

Brumfield, R. T., J. G. Tello, Z. A. Cheviron, M. D. Carling, N. Crochet, And K. V. Rosenberg. 2007. Phylogenetic conservatism and antiquity of a tropical specialization: army-antfollowing in the typical antbirds (Thamnophilidae). Molecular Phylogenetics and Evolution 45:1-13.

Chaves-Campos, J. 2005. Bare-necked Umbrellabird (Cephalopterus glabricollis) foraging at an unusually large assemblage of army ant-following birds. Wilson Bulletin 117:418-420.

Contes-EstradA, R., AND A. EstradA. 1989. Avian attendance and foraging at army-ant swarms in the tropical rain forest of Los Tuxtlas, Veracruz, Mexico. Journal of Tropical Ecology 5:281-292.

Connor, E. F., AND D. SimberlofF. 1979. The assembly of species communities: chance or competition? Ecology 60:1132-1140.

Del Hoyo, J., A. Elliott, And D. A. Christie [eds.]. 2003. Handbook of the birds of the world. Vol. 8. Broadbills to Tapaculos. Lynx Edicions, Barcelona.

DoBBS, R. C., AND P. R. MARTIN. 1998. Migrant bird participation at an army ant swarm in montane Jalisco, Mexico. Wilson Bulletin 110:293-295.

FARIA, C. M. A., AND M. Rodrigues. 2009. Birds and army ants in a fragment of the Atlantic forest of Brazil. Journal of Field Ornithology 80:328-335.

Gochfeld, M., AND G. Tudor. 1978. Ant-following birds in South American subtropical forests. Wilson Bulletin 90:139-141.

Gotelli, N. J. 2000. Null model analysis of species co-occurrence patterns. Ecology 81:2606-2621.

Gotelli, N. J., And G. L. EntSMinger [OnLine]. 2001. EcoSim: Null models software for ecology. Version 7.0. Acquired Intelligence Inc. \& Kesey-Bear. http://homepages.together.net/ gentsmin/ ecosim.htm (6 June 2008).

Gotelli, N. J., AND G. R. GRaves. 1996. Null models in ecology. Smithsonian Institution Press, Washington, D.C.

Gotelli, N. J., AND D. J. MCCABE. 2002. Species co-occurrence: a meta-analysis of J. M. Diamond's assembly rules model. Ecology 83:2091-2096.

Gotwald, W. H. JR. 1995. Army ants: the biology of social predation. Cornell University Press, Ithaca, NY.

Graves, G. R., AND N. J. Gotelli. 1993. Assembly of avian mixedspecies flocks in Amazonia. Proceedings of the National Academy of Sciences 90:1388-1391.

Guilherme, F. A. G., L. P. C. Morellato, and M. A. Assis. 2004. Horizontal and vertical tree community structure in a lowland Atlantic rain forest, southeastern Brazil. Revista Brasileira de Botânica 27:725-737.

HiLty, S. L. 1974. Notes on birds at swarms of army ants in the highlands of Colombia. Wilson Bulletin 86:479-481.

Kumar, A., And S. O'Donnell. 2007. Fragmentation and elevation effects on bird-army ant interactions in neotropical montane forest of Costa Rica. Journal of Tropical Ecology 23:581-590.

Morellato, L. P. C., AND C. F. B. HadDAD. 2000. Introduction: the Brazilian Atlantic forest. Biotropica 32:786-792.

Nascimento, F. H. F. 1994. A sucessão secundária inicial na Mata Atlântica sobre a Serra de Paranapiacaba, Ribeirão Grande, SP. M.Sc. dissertation, Universidade de São Paulo, São Paulo. 
O'Donnell, S., AND A. Kumar. 2006. Microclimatic factors associated with elevational changes in army ant density in tropical montane forest. Ecological Entomology 31:491-498.

O’Donnell, S., J. LattKe, S. Powell, And M. Kaspari. 2007. Army ants in four forests: geographic variation in raid rates and species composition. Journal of Animal Ecology 76:580-589.

ONIKI, Y. 1971. Wandering interspecific flocks in relation to antfollowing birds at Belém, Brazil. Condor 73:372-374.

R Development Core Team [online]. 2007. R: a language and environment for statistical computing. R Foundation for Statistica Computing, Vienna, Austria. http://www.R-project.org (6 June 2008).

Rios, M., G. LondoÑo, AND L. BiAnCUCCI. 2008. Notes on birds that follow army ants in the northern Andes. Ornitología Neotropical 19:137-142.

Robinson, S. K., AND J. TERBORGH. 1995. Interspecific aggression and habitat selection by Amazonian birds. Journal of Animal Ecology 64:1-11.

Rodrigues, M., C. G. Machado, S. M. R. Álvares, and M. Galetti. 1994. Association of the Black-goggled Tanager (Trichothraupis melanops) with flushers. Biotropica 26:472-475.
Stone, L., AnD A. RoberTs. 1990. The checkerboard score and species distributions. Oecologia 85:74-79.

Swartz, M. B. 2001. Bivouac checking, a novel behavior distinguishing obligate from opportunistic species of army-ant-following birds. Condor 103:629-633.

Vielliard, J. M. E., AND W. R. Silva. 2001. Avifauna, p. 125-145. In C. Leonel [ED.], Intervales. Fundação para a Conservação e a Produção Florestal do Estado de São Paulo, São Paulo.

WiLLis, E. O. 1966. The role of migrant birds at swarms of army ants. Living Bird 5:187-231.

WiLlis, E. O. 1985. Behavior and systematics of the Gray-headed Tanager (Trichothraupis penicillata). Naturalia 10:113-145.

Willis, E. O., AND Y. ONIKI. 1978. Birds and army ants. Annual Review of Ecology and Systematics 9:243-263.

Willis, E. O., AND Y. ONIKI. 1992. As aves e as formigas de correição. Boletim do Museu Paraense Emílio Goeldi 8:123-150.

WiLlson, S. K. 2004. Obligate army-ant-following birds: a study of ecology, spatial movement patterns, and behavior in Amazonian Peru. Ornithological Monographs 55. 